\title{
Gingival calcifying epithelial odontogenic tumor: case report and review of the literature comprising a period of 44 years.
}

\author{
Eduardo Costa Studart-Soares ${ }^{1}$, Fábio Wildson Gurgel-Costa ${ }^{2}$, Diego Felipe Silveira-Esses ${ }^{3}$, Eugênio Pacce- \\ lli Alves-Filho ${ }^{4}$, Ana Paula Negreiros Nunes-Alves ${ }^{5}$
}

\footnotetext{
${ }^{1}$ Associate professor, D.D.S., M.S., Ph.D., Division of Stomatology and Oral Surgery, Department of Clinical Dentistry, School of Dentistry, Federal University of Ceará, Brazil.

${ }^{2}$ Assitant professor, D.D.S., M.S., Division of Stomatology, Department of Clinical Dentistry, School of Dentistry, Federal University of Ceará Campus Sobral.

${ }^{3}$ Resident in Oral and Maxillofacial Surgery, Walter Cantídio University Hospital, Federal University of Ceará.

${ }^{4}$ Graduate Student, School of Dentistry, Federal University of Ceará.

${ }_{5}^{5}$ Associate professor, D.D.S., M.D., Ph.D., Division of Oral Pathology, Department of Clinical Dentistry, Federal University of Ceará.
}

Correspondence:

Coordenação do Curso de Odontologia

da Universidade Federal do Ceará Campus Sobral;

Av. Comte. Maurocélio Rocha Pontes, $s / n{ }^{\circ}$ Derby;

CEP 62.041-040, Sobral-Ce, Brazil.

E-mail:fwildson@yahoo.com.br

\begin{abstract}
Studart Soares EC, Gurgel Costa FW, Silveira Esses DF, Alves Filho EP, Nunes Alves APN. Gingival calcifying epithelial odontogenic tumor: case report and review of the literature comprising a period of 44 years. J Clin Exp Dent. 2011;3(5):e491-6.

http://www.medicinaoral.com/odo/volumenes/v3i5/jcedv3i5p491.pdf
\end{abstract} Article Number: $50589 \quad$ http://www.medicinaoral.com/odo/indice.htm
(C) Medicina Oral S. L. C.I.F. B 96689336 - eISSN: 1989-5488 eMail: jced@jced.es

\begin{abstract}
Calcifying epithelial odontogenic tumors are rare odontogenic neoplasms that account for approximately $1 \%$ of all odontogenic tumors. The extraosseous variant is extremely rare, with only few cases being described in the literature. To our knowledge, only 22 cases have been reported over a period of 44 years. Therefore, the aim of this study was to present a critical literature review comprising the period from 1966 to 2010. In addition, we discuss the clinical presentation, diagnosis, and subsequent treatment of a patient with a gingival calcifying epithelial odontogenic tumor in the anterior mandible. This study shows that even though being an extremely rare neoplasm the gingival calcifying epithelial odontogenic tumor should be included in the differential diagnosis by general dentists of gingival lesions due to its clinical similarity to other oral hyperplastic or reactive lesions. A conservative surgical approach can be adopted in view of the nonaggressive behavior of this tumor. Recurrence is low and the prognosis is excellent.
\end{abstract}

Key words: Calcifying epithelial odontogenic tumor, gingiva, and peripheral odontogenic tumor. 


\section{Introduction}

Odontogenic tumors comprise a diverse group of exceptional lesions derived from epithelial elements of the tooth-forming apparatus that account for about $1 \%$ of all jaw tumors (1). According to Mosqueda-Taylor (2), some of these tumors are hamartomas that present variable degrees of differentiation, whereas the remaining ones are benign or malignant neoplasms of variable aggressiveness characterized by a metastatic potential. Calcifying epithelial odontogenic tumors (CEOTs) located in the oral and maxillofacial region are well-recognized examples of odontogenic tumors that display a broad spectrum of clinical and histopathologic features (3). CEOTs are rare benign odontogenic neoplasms of the jaws that account for approximately $1 \%$ of all intraosseous odontogenic tumors $(4,5)$. On the other hand, the extraosseous variant of CEOT is extremely rare, with only few cases being described in the literatures. To our knowledge, only 22 cases have been reported over a period of 44 years (6-24). Therefore, the aim of this study was to present a critical literature review comprising the period from 1966 to 2010. In addition, we discuss the clinical presentation, diagnosis, and subsequent treatment of a patient with a gingival calcifying epithelial odontogenic tumor (GCEOT) in the anterior mandible

\section{Case Report}

A 28-year-old systemically healthy male patient presented to the Division of Stomatology, School of Dentistry, Federal University of Ceará (Brazil), complaining of an asymptomatic slow-growing swelling in the anterior gingiva, which had been noted 15 months earlier.
The onset was spontaneous and there was no history of trauma or functional impairment. Extraoral examination and palpation revealed a cervical lymph node chain of normal size and consistency. Clinical examination (Fig. 1A) showed a 2-cm firm, sessile gingival nodule covered with normal-appearing tissue, which involved the anterior gingival mandibular region. The surface of the lower portion of the mass was telangiectatic. Periapical radiography was care out before surgical intervention and was returned to the patient. Its description was consistent with a peripheral lesion due to absence of central involvement. However, the patient lost $\mathrm{x}$-ray radiography and thus this photography could not be included in our illustrations. The decision was made to excise the lesion under local anesthesia (Fig. 1B-D). During the surgical procedure, the lesion was easily enucleated and the bone surface was curetted. No relevant findings were observed. The wound was closed with 4-0 black silk sutures. The specimen was fixed in formalin and submitted to histopathologic analysis (hematoxylin-eosin stain). Microscopic examination (Figs. 2 and 3) showed layers of stratified squamous oral mucosa and fibrous stroma. Islands and solid masses consisting of polygonal cells with eosinophilic cytoplasm and a hyperchromatic nucleus, eosinophilic amorphous material, and concentric calcifications (Liesegang rings) were found deep in the connective tissue. Based on the microscopic findings, the final diagnosis was a gingival calcifying epithelial odontogenic tumor. The patient reported minimal discomfort after surgery. In addition, no recurrence of the tumor was observed over a follow-up period of 4 years.

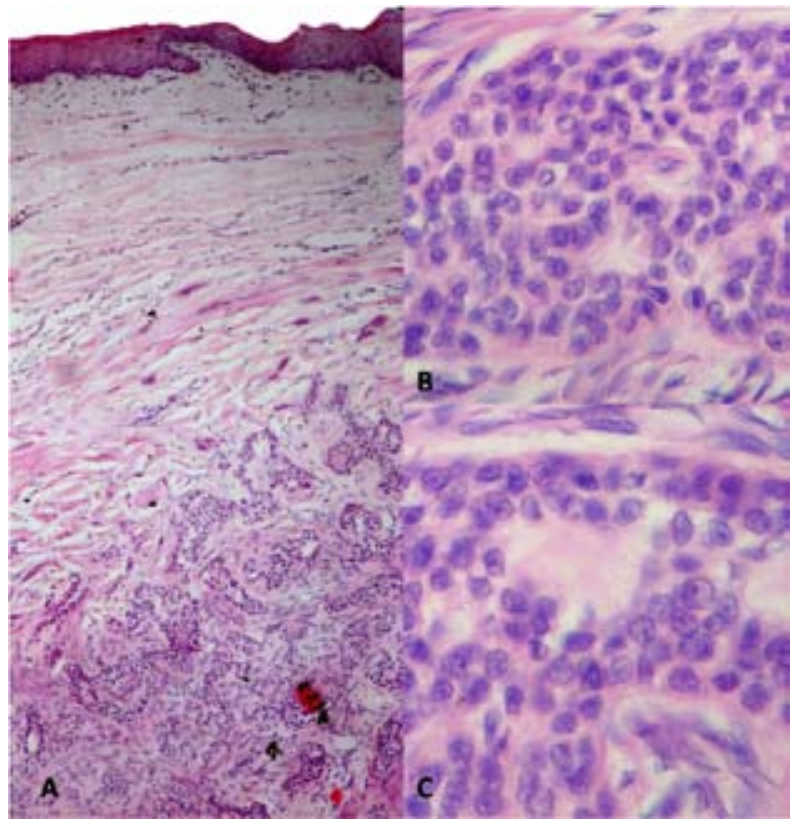

Fig. 2. A) Photomicrograph of peripheral CEOT in a connective tissue of the gingiva (HE, x100); B, C) islands of polyhedral and hyperchromatic cells in an eosinophilic stroma (HE, x400).

Fig. 1. Clinical appearance (A), surgical approach $(B, C)$, and $m a-$ croscopic view of the specimen (D). 


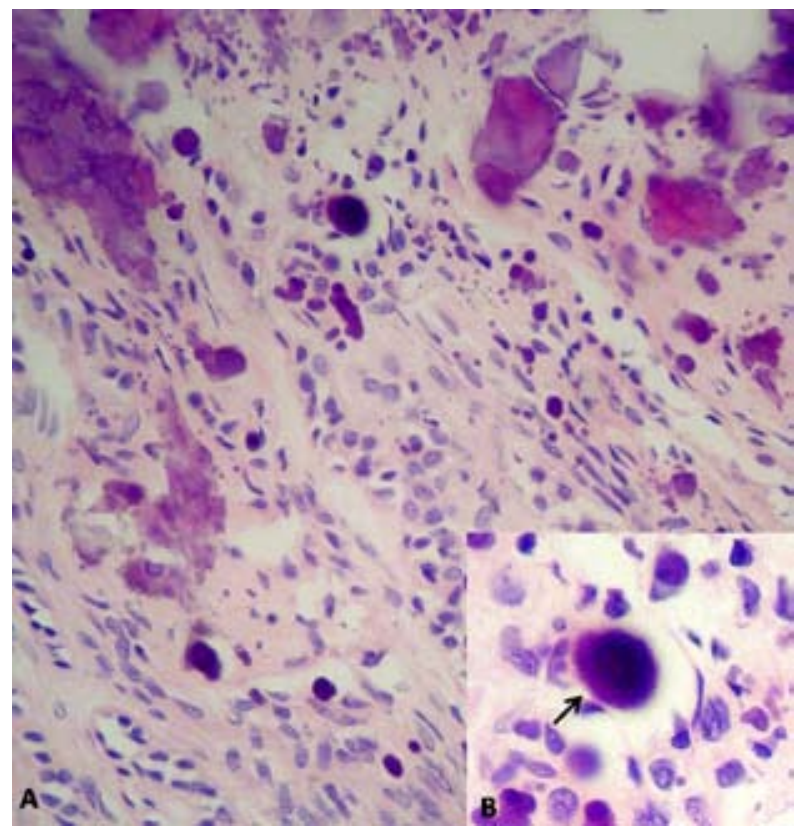

Fig. 3. A) Nests of epithelial cells with calcification, amorphous eosinophilic amyloid-like material, and Liesegang rings (HE, x200). B) High-power view of the Liesegang ring (HE, x400).

\section{Literature Review}

A MEDLINE search of the literature comprising the period from 1966 to 2010 was performed, in which all studies of histopathologically confirmed GCEOTs, including detailed demographic data, were retrieved. Twenty-two cases of GCEOT were identified (Table 1). Additionally, the epidemiological profile of patients seen at the Division of Stomatology, School of Dentistry, Federal University of Ceará, Brazil, between March 1999 and May 2009 were reviewed. Analysis of 1852 consecutive biopsy specimens yielded one case diagnosed as extraosseous CEOT.

Patient age ranged from 12 to 71 years (mean: 40.1 years); $60 \%$ of the cases were females and $40 \%$ were males, with a female to male ratio of $1.5: 1$. The peak incidence of the tumors was observed in the fourth decade of life. Age ranged from 16 to 71 years (mean: 44.5) in females and from 12 to 64 years (mean: 33.8 years) in males. Tumor size ranged from 0.5 to $3.0 \mathrm{~cm}$ (mean: $1.37 \mathrm{~cm})$. Ten available cases were located in the maxilla $(47.62 \%)$ and 11 cases in the mandible (52.38\%), with an equal distribution in the anterior and posterior region. The maxilla to mandible ratio was $1: 1.22$. The anterior region of the jaws was affected in $57.14 \%$ of the cases. The histologic variants of GCEOT observed in the present study were, in order of decreasing case number, clear cell $(\mathrm{n}=12)$, conventional $(\mathrm{n}=9)$, and hybrid $(\mathrm{n}=$ $1)$. Recurrence was reported in $5 \%$ of peripheral cases.

\section{Discussion}

Peripheral odontogenic tumors are particularly rare con- ditions affecting the jaws. Retrospective studies and case reports are scarce. Buchner et al. (20) reported 45 cases of peripheral odontogenic tumor that included peripheral odontogenic fibroma, peripheral ameloblastoma, peripheral calcifying cystic odontogenic tumor, peripheral ameloblastic fibroma, peripheral ameloblastic carcinoma and only one case of peripheral Pindborg tumour. These lesions corresponded to $0.05 \%$ of all tumors diagnosed over a period of 20 years (1984 to 2004) at the Pacific Oral and Maxillofacial Pathology Laboratory, University of the Pacific, San Francisco, CA, USA. Ide et al. (25) identified 30 cases of gingival odontogenic tumor among 39,660 oral biopsies available over a period of 34 years. The present case was diagnosed among 1852 consecutive biopsy specimens obtained between 1999 and 2009 at the Division of Stomatology, School of Dentistry, Federal University of Ceará, Brazil, corresponding to $0.05 \%$ of all oral biopsies analyzed at our institution. Other peripheral tumours were not observed in our sample.

Single cases of odontogenic neoplasms originating in the attached gingiva mainly include odontogenic fibroma, ameloblastoma, adenomatoid odontogenic tumor, odontogenic myxoma, ameloblastic fibroma, odontoma, calcifying cystic odontogenic tumor, squamous odontogenic tumor, keratocystic odontogenic tumor, and CEOT. Some of these tumors are exceedingly rare $(20,25,26)$. CEOT was first described by Jens J. Pindborg in 1955 as a separate entity among epithelial odontogenic tumors and the eponym "Pindborg tumor" has also been used for this pathologic condition (9). The first reports of extraosseous CEOT date back to 1966 when Pindborg published two cases of gingival growth in the anterior jaw region of young patients (6). Since their recognition, 21 cases of these tumors have been published in the English literature (Table 1).

The initial consensus regarding the pathogenesis of CEOT was attributed to Pindborg in 1955. He stated that the CEOT was indeed of odontogenic origin reduced organ enamel-related due to previously case had been associated to unerupted teeth (6). However, according to Philipsen et al. (5), with the reports of central cases not presenting unerupted tooth and gingival variants, other sources of origin were debated. The soft tissue location of CEOTs strongly suggests that these tumors may arise from rests of dental lamina or from basal cells of the oral epithelium. After disintegration of the dental lamina complex, numerous epithelial remnants (rests of Serres) persist in the jaw bones and supraperiosteally in the gingiva when odontogenesis is completed. Furthermore, focal proliferation of the basal layer of the gingival epithelium has also been proposed as a possible origin (19). Clinically, GCEOT is a slow-growing solitary painless mass, although Abrahão et al. and de Oliveira et al. reported the presence of two lesions in the same patient. 


\begin{tabular}{|c|c|c|c|c|c|c|c|c|}
\hline Author & Year & $\begin{array}{l}\text { Age } \\
\text { (yrs) }\end{array}$ & Sex & $\begin{array}{l}\text { Size } \\
(\mathrm{cm})\end{array}$ & $\mathbf{N}$ & Gingival area & $\begin{array}{l}\text { Histologic va- } \\
\text { riant }\end{array}$ & $\begin{array}{l}\text { Recu- } \\
\text { rrence }\end{array}$ \\
\hline \multirow[t]{2}{*}{ Pindborg (6) } & 1966 & 29 & $\mathrm{~F}$ & NA & 1 & $\begin{array}{l}\text { Lateral incisor/Maxi- } \\
\text { lla }\end{array}$ & Conventional & No \\
\hline & & 16 & $\mathrm{~F}$ & NA & 1 & $\begin{array}{l}\text { Lateral incisor/Man- } \\
\text { dible }\end{array}$ & Conventional & No \\
\hline Abrams, Howell (7) & 1967 & 16 & $\mathrm{~F}$ & 0.5 & 1 & NA & Clear Cell & No \\
\hline Decker, Lafitte (8) & 1967 & 40 & M & 2 & 1 & Premolar/Mandible & Conventional & No \\
\hline Patterson et al. (9) & 1969 & 12 & M & 0.7 & 1 & $\begin{array}{l}\text { Central incisor/Man- } \\
\text { dible }\end{array}$ & Conventional & No \\
\hline Krolls, Pindborg (10) & 1974 & 60 & NA & NA & 1 & Anterior/Mandible & Conventional & No \\
\hline Wertheimer et al. (11) & 1977 & 20 & M & 1.5 & 1 & $\begin{array}{l}\text { Lateral incisor-pre- } \\
\text { molar/Maxilla }\end{array}$ & Clear Cell & No \\
\hline \multirow[t]{2}{*}{ Ai-Ru et al. (12) } & 1982 & 32 & $\mathrm{~F}$ & NA & 1 & $\begin{array}{l}\text { Premolar-Molar/ } \\
\text { Mandible }\end{array}$ & Clear Cell & No \\
\hline & & 47 & $\mathrm{~F}$ & NA & 1 & $\begin{array}{l}\text { Canine-Premolar/ } \\
\text { Mandible }\end{array}$ & Clear Cell & No \\
\hline Takeda et al. (13) & 1983 & 31 & $\mathrm{~F}$ & 1.5 & 1 & Molar/Maxilla & Conventional & No \\
\hline Ng, Siar (14) & 1996 & 52 & M & NA & 1 & $\begin{array}{l}\text { Canine-premolar/ } \\
\text { Maxilla }\end{array}$ & Conventional & No \\
\hline \multirow[t]{2}{*}{ Houston, Fowler (15) } & 1997 & 64 & M & 1.5 & 1 & Premolar/Maxilla & Clear Cell & No \\
\hline & & 27 & M & 1.4 & 1 & Premolar/Mandible & Clear Cell & No \\
\hline Orsinid et al. (16) & 2000 & 32 & M & NA & 1 & $\begin{array}{l}\text { Lateral incisor-cani- } \\
\text { ne/Maxilla }\end{array}$ & Clear Cell & No \\
\hline Anavi et al. (17) & 2003 & 27 & M & 1.0 & 1 & $\begin{array}{l}\text { Canine-premolar/ } \\
\text { Mandible }\end{array}$ & Clear Cell & No \\
\hline Mesquita et al. (18) & 2003 & 48 & $\mathrm{~F}$ & 2.0 & 1 & Canine/Maxilla & Clear Cell & No \\
\hline Manor et al. (19) & 2004 & 19 & NA & 0.8 & 1 & Molar/Mandible & Conventional & No \\
\hline Buchner et al. (20) & 2006 & 71 & $\mathrm{~F}$ & NA & 1 & NA & Conventional & NA \\
\hline Abrahão et al. (21) & 2009 & 40 & $\mathrm{~F}$ & NA & 2 & Premolar/Mandible & Conventional & Yes \\
\hline de Oliveira et al. (22) & 2009 & 43 & $\mathrm{~F}$ & 2.0 & 2 & $\begin{array}{l}\text { Premolar/Maxilla } \\
\text { Incisor/Mandible }\end{array}$ & Clear Cell & No \\
\hline Habibis et al. (23) & 2009 & 70 & $\mathrm{~F}$ & 0.5 & 1 & $\begin{array}{l}\text { Lateral incisor-cani- } \\
\text { ne/Maxilla }\end{array}$ & Clear Cell & No \\
\hline Etit et al. (24) & 2010 & 62 & $\mathrm{~F}$ & 3.0 & 1 & Molar/Maxilla & Hybrid $†$ & No \\
\hline Present case & 2010 & 28 & $\mathrm{M}$ & 2.0 & 1 & Incisor/Mandible & Conventional & No \\
\hline
\end{tabular}

Yrs, yeas; $\mathrm{cm}$, centimeters; N, number of lesions per patient; F, female; M, male; NA, not available. $\dagger$ Hybrid peripheral odontogenic tumor added by ameloblastoma areas.

Table 1. Epidemiological profile of GCEOT over a 44-year period 
There is a slight female gender preference, with most cases occurring in middle aged women (Table 1). In contrast, the present case of GCEOT occurred in a 28 -yearold man who showed typical clinical and histopathologic features. The covering mucosa presented a normal color, in agreement with previous reports (19-22), but the surface of the lower portion of the mass was telangiectatic (Fig. 1A). This finding was probably due to the anterior location and consequent functional overload of the masticatory muscles.

Clinical differences between central and peripheral CEOT have been described. Anatomically, a maxilla to mandible ratio of 1:2 has been reported for the intraosseous types (5) and mandibular lesions are mainly found in the premolar/molar region. In contrast, the present case occurred in the anterior region of the jaws, which is the most common gingival site of CEOT with a slight predilection to mandible if we added our case to the other previously reported (Table 1). There is no explanation for the specific anterior location of this tumor.

Like other peripheral odontogenic tumors, GCEOTs mainly appear as nonspecific sessile exophytic masses in anterior gingival tissue and can mimic a wide variety of oral lesions, including gingivitis, pyogenic granuloma, peripheral giant cell lesion, peripheral ossifying fibroma, and fibrous hyperplasia $(16,19)$. However, the etiology of these conditions is usually known and careful examination is necessary when any local irritant is defined or the lesion recurs after surgical treatment (19). In the present case, a provisional diagnosis of peripheral ossifying fibroma was made. This diagnosis was based on the clinical and radiographic appearance of the mass, including normal-appearing mucosa in contrast to the red or purple color characteristic of gingivitis and pyogenic granuloma and peripheral giant cell lesions, respectively, and the presence of radiopaque clusters not observed in fibrous hyperplasia (27). Peripheral giant cell lesions usually produce a superficial 'peripheral-cuff' radiolucency that is not observed in ossifying fibroma. On the other hand, the observation of radiopacity in the latter has been associated with mild resorption of the crest of the ridge (16). As observed in the present case, GCEOT may appear as a radiolucency with scattered radiopaque foci. Histologically, small amounts of mineralized material might be observed, which is a common finding in peripheral CEOT types (5).

Over the years, the histology of CEOTs has been well documented. Ai-Ru et al (12). subclassified this tumor into four distinct microscopic patterns, although two or more types may be present in the same tumor. Type 1 consists of sheets, nests and masses of polyhedral epithelial cells exhibiting prominent intercellular bridges, marked nuclear size variation, regular nuclear pleomorphism, scarce mitotic figures, and calcified corpuscles in the fibrous stroma. Type 2 is characterized by a cri- briform arrangement of tumor cells, less nuclear cell pleomorphism, absence of prominent intercellular bridges, and masses of calcified tissue showing Liesegang rings. Type 3 consists of scattered or densely populated tumor cells accompanied by marked cellular pleomorphism in a myxoid stroma and frequent multinucleated giant cells. Type 4 is characterized by small nests and cords of epithelial cells, some of them containing abundant cytoplasm separated by fibrous stromal tissue. In addition, several cellular variants such as clear cell, pigmented, Langerhans cell containing, bone and cementum forming, myoepithelial cell, and noncalcifying subtypes have been reported $(5,14)$. The present case was classified as type 1, except for the presence of large scattered calcified masses.

According to the histologic classification of Ai-Ru et al (12). and analysis of the data in Table 1, GCEOTs can be divided into three main variants: clear cell, conventional, and hybrid. The first case of peripheral clear cell CEOT was reported by Abrams and Howell in 1967 (7), which was characterized by the presence of sheets of polyhedral epithelium with abundant eosinophilic cytoplasm and areas containing large cells with clear frothy cytoplasm and distinct cell borders. This variant was the most prevalent in the present review, with 11 cases (52.4\%) published in the international literature. In addition, it is important to note that the occurrence of clear cells in odontogenic tumors may indicate a progressive or even malignant behavior, in contrast to specimens in which no clear cells are identified microscopically (4). The conventional variant included all non-hybrid cases presenting usual features and no clear cells and was the second most common condition, corresponding to $42.9 \%$ of the cases. The third pattern was the hybrid variant, which is a recent rare gingival tumor. Only one case was reported by Etit et al. (24), in which the CEOT presented unusual features of ameloblastoma. CEOT-like areas in adenomatoid odontogenic tumors have been described for the intraosseous variants of CEOT and are called combined epithelial odontogenic tumors (28).

In the present study, an excisional biopsy was performed due to the slow gingival growth of the mass, small size, and clinical appearance similar to that of peripheral ossifying fibroma. This similarity between peripheral odontogenic tumors and non-neoplastic hyperplastic gingival lesions may lead to an incorrect clinical diagnosis and inadequate treatment. Abrahão et al. (21) reported a unique case of bilateral GCEOT presumptively diagnosed as bilateral pyogenic granuloma that was surgically excised without bone curettage and recurred bilaterally one year later. Thus, although GCEOT is a nonaggressive tumor and recurrence is rare, a favorable prognosis depends on complete excision of the tumor and effective curettage. Furthermore, malignant transformation is an extremely rare phenomenon, which has only been des- 
cribed for one case of central CEOT.

In summary, intraosseous Pindborg tumors are uncommon odontogenic tumors and even though extremely rare peripheral CEOTs, should be included by general dentists in the differential diagnosis of gingival lesions. The present study demonstrates the importance of correct initial management of gingival overgrowth. Although complete surgical excision generally leads to cure, the lack of complaints and recurrence of GCEOT observed here after 4 years of follow-up do not invalidate recommendations for long-term monitoring, especially because of the limited knowledge about the longterm behavior of this tumor.

\section{References}

1. Jing W, Xuan M, Lin Y, Wu L, Liu L, Zheng X, et al. Odontogenic tumours: a retrospective study of 1642 cases in a Chinese population. Int J Oral Maxillofac Surg. 2007; 36:20-25.

2. Mosqueda-Taylor A. New findings and controversies in odontogenic tumors. Med Oral Patol Oral Cir Bucal. 2008; 13:E555-558.

3. Belmonte-Caro R, Torres-Lagares D, Mayorga-Jimenez F, GarciaPerla García A, Infante-Cossio P, Gutierrez-Perez JL. Calcifying epithelial odontogenic tumor (Pindborg tumor). Med Oral. 2002; 7:309-315.

4. Rangel AL, da Silva AA, Ito FA, Lopes MA, de Almeida OP, Vargas PA. Clear cell variant of calcifying epithelial odontogenic tumor: is it locally aggressive?. J Oral Maxillofac Surg. 2009; 67:207-211.

5. Philipsen HP, Reichart PA. Calcifying epithelial odontogenic tumor: biological profile based on 181 cases from literature. Oral Oncol 2000; 36:17-26.

6. Pindborg JJ. The calcifying epithelial odontogenic tumor. Review of literature and report of an extra-osseous case. Acta Odontol Scand. 1966; 24:419-430.

7. Abrams AM, Howell FV. Calcifying epithelial odontogenic tumors. Report of four cases. J Am Dent Assoc. 1967; 1231-1240.

8. Decker RM, Lafitte HB. Peripheral calcifying epithelial odontogenic tumor. Oral Surg Oral Med Oral Pathol Oral Radiol Endod. 1967; 23:398-402.

9. Patterson JT, Martin TH, DeJean EK, Burzynski NJ. Extraosseous calcifying epithelial odontogenic tumor. Report of a case. Oral Surg Oral Med Oral Pathol. 1969; 27:363-367.

10. Krolls SO, Pindborg JJ. Calcifying epithelial odontogenic tumor. A survey of 23 cases and discussion of histomorphologic variations. Arch Pathol. 1974; 98:206-210.

11. Wertheimer FW, Zielinski RJ, Wesley RK. Extraosseous calcifying epithelial odontogenic tumor (Pindborg tumor). Int J Oral Surg. 1977; 6:266-269.

12. Ai-Ru L, Zhen L, Jian S. Calcifying epithelial odontogenic tumours: a clinicopathologic study of nine cases. J Oral Pathol Med. 1982; 11:399-406

13. Takeda Y, Suzuki A, Sekiyama S. Peripheral calcifying epithelial odontogenic tumor. Oral Surg Oral Med Oral Pathol. 1983; 56:7175.

14. $\mathrm{Ng} \mathrm{KH}$, Siar $\mathrm{CH}$. A clinicopathological and immunohistochemical study of the calcifying epithelial odontogenic tumour (Pindborg tumour) in Malaysians. J Laryngol Otol. 1996; 110:757-762.

15. Houston GD, Fowler CB. Extraosseous calcifying epithelial odontogenic tumor: report of two cases and review of the literature. Oral Surg Oral Med Oral Pathol Oral Radiol Endod. 1997; 83:577-583.

16. Orsini G, Favia G, Piattelli A. Peripheral clear cell calcifying epithelial odontogenic tumor. Report of a case. J Periodontol. 2000; 71:1177-1180.

17. Anavi Y, Kaplan I, Citir M, Calderon S. Clear-cell variant of calcifying epithelial odontogenic tumor: clinical and radiographic characteristics. Oral Surg Oral Med Oral Pathol Oral Radiol Endod. 2003; 95:332-339.
18. Mesquita RA, Lotufo MA, Sugaya NN, De Araújo NS, De Araújo VC. Peripheral clear cell variant of calcifying epithelial odontogenic tumor: Report of a case and immunohistochemical investigation. Oral Surg Oral Med Oral Pathol Oral Radiol Endod. 2003; 95:198-204.

19. Manor Y, Mardinger O, Katz J, Taicher S, Hirshberg A. Peripheral odontogenic tumours--differential diagnosis in gingival lesions. Int J Oral Maxillofac Surg. 2004; 33:268-273.

20. Buchner A, Merrell PW, Carpenter WM. Relative frequency of peripheral odontogenic tumors: a study of 45 new cases and comparison with studies from the literature. J Oral Pathol Med. 2006; 35:385-391.

21. Abrahão AC, Camisasca DR, Bonelli BR, Cabral MG, Lourenço $\mathrm{SQ}$, Torres SR, et al. Recurrent bilateral gingival peripheral calcifying epithelial odontogenic tumor (Pindborg tumor): a case report. Oral Surg Oral Med Oral Pathol Oral Radiol Endod. 2009; 108:e66-71.

22. de Oliveira MG, Chaves AC, Visioli F, Rojas EU, Moure SP, Romanini J, et al. Peripheral clear cell variant of calcifying epithelial odontogenic tumor affecting 2 sites: report of a case. Oral Surg Oral Med Oral Pathol Oral Radiol Endod. 2009; 107:407-411.

23. Habibi A, Saghravanian N, Zare R, Jafarzadeh H. Clear cell variant of extraosseous calcifying epithelial odontogenic tumor: a case report. J Oral Sci. 2009; 51:485-488.

24. Etit D, Uyaroglu MA, Erdogan N. Mixed odontogenic tumor: ameloblastoma and calcifying epithelial odontogenic tumor. Indian J Pathol Microbiol. 2010; 53:122-124.

25. Ide F, Obara K, Mishima K, Saito I, Horie N, Shimoyama T, et al. Peripheral odontogenic tumor: a clinicopathologic study of 30 cases. General features and hamartomatous lesions. J Oral Pathol Med. 2005; 34:552-527.

26. Ide F, Mishima K, Saito I, Kusama K. Rare peripheral odontogenic tumors: report of 5 cases and comprehensive review of the literature. Oral Surg Oral Med Oral Pathol Oral Radiol Endod. 2008; 106:e22-28.

27. Zhang W, Chen Y, An Z, Geng N, Bao D. Reactive gingival lesions: a retrospective study of 2,439 cases. Quintessence Int. 2007; 38:103-110.

28. Mosqueda-Taylor A, Carlos-Bregni R, Ledesma-Montes C, Fillipi RZ, de Almeida OP, Vargas PA. Calcifying epithelial odontogenic tumor-like areas are common findings in adenomatoid odontogenic tumors and not a specific entity. Oral Oncol. 2005; 41:214-215. 